\title{
Impact of Silicon Nanoparticles on the Antioxidant Compounds of Tomato Fruits Stressed by Arsenic
}

\author{
Magín González-Moscoso ${ }^{1}{ }^{(}$, Nadia Valentina Martínez-Villegas ${ }^{2}$, Gregorio Cadenas-Pliego $\left.{ }^{3}{ }^{(}\right)$, \\ Adalberto Benavides-Mendoza ${ }^{4}$, María del Carmen Rivera-Cruz ${ }^{5}$, Susana González-Morales ${ }^{6}$ (D) \\ and Antonio Juárez-Maldonado $7, *$ (D) \\ 1 Doctorado en Ciencias en Agricultura Protegida, Universidad Autónoma Agraria Antonio Narro, Saltillo, \\ Coahuila 25315, Mexico; magingonmos@gmail.com \\ 2 IPICyT, Instituto Potosino de Investigación Científica y Tecnológica, San Luis Potosí SLP 78216, Mexico; \\ nadia.martinez@ipicyt.edu.mx \\ 3 Centro de Investigación en Química Aplicada, Saltillo, Coahuila 25294, Mexico; \\ gregorio.cadenas@ciqa.edu.mx \\ 4 Departamento de Horticultura, Universidad Autónoma Agraria Antonio Narro, Saltillo, Coahuila 25315, \\ Mexico; adalberto.benavides@uaaan.edu.mx \\ 5 Colegio de Postgraduados Campus Tabasco, H. Cárdenas, Tabasco 86570, Mexico; mariari@colpos.mx \\ 6 CONACyT-Departamento de Horticultura, Universidad Autónoma Agraria Antonio Narro, Saltillo, \\ Coahuila 25315, Mexico; qfb_sgm@hotmail.com \\ 7 Departamento de Botánica, Universidad Autónoma Agraria Antonio Narro, Saltillo, Coahuila 25315, Mexico \\ * Correspondence: antonio.juarez@uaaan.edu.mx or juma841025@hotmail.com; Tel.: +52-844-411-0317
}

Received: 23 October 2019; Accepted: 20 November 2019; Published: 23 November 2019

\begin{abstract}
Tomato fruit is rich in antioxidant compounds such as lycopene and $\beta$-carotene. The beneficial effects of the bioactive compounds of tomato fruit have been documented as anticancer activities. The objective of this research was to determine whether arsenic (As) causes changes in the content of antioxidant compounds in tomato fruits and whether Silicon nanoparticles $\left(\mathrm{SiO}_{2} \mathrm{NPs}\right)$ positively influence them. The effects on fruit quality and non-enzymatic antioxidant compounds were determined. The results showed that As decreased the oxide-reduction potential (ORP), while lycopene and $\beta$-carotene were increased by exposure to As at a low dose $\left(0.2 \mathrm{mg} \mathrm{L}^{-1}\right)$, and proteins and vitamin $\mathrm{C}$ decreased due to high doses of As in the interaction with $\mathrm{SiO}_{2} \mathrm{NPs}$. A dose of $250 \mathrm{mg} \mathrm{L}^{-1}$ of $\mathrm{SiO}_{2} \mathrm{NPs}$ increased glutathione and hydrogen peroxide $\left(\mathrm{H}_{2} \mathrm{O}_{2}\right)$, and phenols decreased with low doses of As and when they interacted with the NPs. As for the flavonoids, they increased with exposure to As and $\mathrm{SiO}_{2} \mathrm{NPs}$. The total antioxidant capacity, determined by the ABTS (2,2'-azino-bis[3-ethylbenzthiazolin-6-sulfonic acid]) test, showed an increase with the highest dose of As in the interaction with $\mathrm{SiO}_{2} \mathrm{NPs}$. The application of As at low doses induced a greater accumulation of bioactive compounds in tomato fruit; however, these compounds decreased in high doses as well as via interaction with $\mathrm{SiO}_{2} \mathrm{NPs}$, indicating that there was an oxidative burst.
\end{abstract}

Keywords: bioactive compounds; oxidative stress; lycopene; hydrogen peroxide; $\beta$-carotene

\section{Introduction}

Tomato is the second most important crop in the world from an economic point of view [1]. However, tomato fruit is also important in the human diet because it can provide vitamins and a wide range of bioactive molecules [2], such as vitamins $C$ and E, flavonoids, and phenols [3]. Lycopene is one of the strongest natural antioxidants known and is the main carotene in ripe tomatoes [4], and together with $\beta$-carotene, it is effective in eliminating peroxyl radicals [5]. These compounds seem to play a 
role against the development of different types of cancer and cardiovascular diseases due to their antioxidant capacity [6,7], which is why they are very important for human health.

There are many biotic and abiotic factors that influence the growth and development of a tomato crop, which can modify the quality of the fruit. One of these is arsenic (As), a highly toxic metalloid for plants and humans $[8,9]$. It is known that irrigation water contaminated by As causes a gradual and continuous accumulation in the soil that affects the sustainability of agriculture, decreases crop yield, and contaminates the food chain $[10,11]$. The concentration of As in rice grains has been reported to range from 93 to $989 \mu \mathrm{g} \mathrm{kg}-1$ dry weight [12], in mango fruits from 0.6 to $50 \mu \mathrm{g} \mathrm{kg}$-1 fresh weight [13], and from 2 to $13 \mu \mathrm{g} \mathrm{g}^{-1}$ of dry weight in tomatoes [14]. In addition, the capacity of a tomato plant to absorb and translocate As is of vital importance, since the fruit is the organ of consumption [15].

Arsenic induces the production of reactive oxygen species (ROS), which lead to lipid peroxidation $[16,17]$. Antioxidant metabolites synthesized by plants to avoid ROS-induced damage during oxidative stress are constitutively present in fruits and at different levels according to their stage of maturation [18]. The oxidative stress in tomato fruit increases in a coordinated manner with the ripening of the fruit and reaches a peak in the final stages, which triggers metabolic changes and softening of the fruit [19].

Currently, nanotechnology is used for different purposes in agriculture for the promotion of plant growth [20]. Nanoparticles (NPs, materials with a dimension of less than $100 \mathrm{~nm}$ ) are noteworthy and can be considered biostimulants, since in specific ranges of concentration, generally at low levels, they increase plant growth [21]. NPs have been implicated in inducing a better quality of tomato fruit and increasing lycopene under conditions of abiotic stress [22]. Silicon nanoparticles (Si NPs) increase the yield of cucumber fruit [23]. Silicon decreases the toxic effect of heavy metals by reducing uptake and translocation to the aerial parts of plants [24]. It can also inhibit the negative impact of oxidative stress caused by As by restricting the production of ROS, improving the action of various antioxidant compounds, and regulating the osmotic potential of the cell [25]. Considering the above, the objective of the present investigation was to determine the impact of the $\mathrm{SiO}_{2} \mathrm{NPs}$ on the antioxidant content of tomato fruits obtained from plants developed under conditions of arsenic stress.

\section{Materials and Methods}

\subsection{Fruit Sampling}

A tomato crop (Solanum lycopersicum L.) var. "Sun 7705" (Nunhems Amsterdam Netherlands B.V. Napoleonsweg 1526083 AB Nunhem Nederland), of type saladette and indeterminate, was grown. A total of 216 plants were established for the experiment. A soil-less culture system was used, which involved placing the plants in $12 \mathrm{~L}$ black polyethylene bags containing a mixture of Peat moss and perlite (1:1) as substrate. A Steiner nutrient solution [26] was used for crop nutrition.

Arsenic contamination was simulated in the irrigation water, where different concentrations of the contaminant were applied $\left(0,0.2,0.4,0.8,1.6\right.$, and $3.2 \mathrm{mg} \mathrm{As}^{-1}$ water). In addition, different doses of silicon dioxide nanoparticles $\left(\mathrm{SiO}_{2} \mathrm{NPs}\right)\left(0,250\right.$, and $\left.1000 \mathrm{mg} \mathrm{L}^{-1}\right)$ were applied. The $\mathrm{SiO}_{2}$ NPs (10 mL to each plant) were applied to soil at intervals of three weeks from transplanting, with a total of six applications. In total, 18 treatments were evaluated. $\mathrm{SiO}_{2} \mathrm{NPs}$ of $10-20 \mathrm{~nm}$ size had a spherical morphology, a surface area of $160 \mathrm{~m}^{2} \mathrm{~g}^{-1}$, and a bulk density of $0.08-0.1 \mathrm{~g} \mathrm{~cm}^{-3}$ (SkySpring Nanomaterials Inc., Houston, TX, USA). Arsenic was applied as sodium arsenate heptahydrate $\left(\mathrm{Na}_{2} \mathrm{HAsO}_{4} \cdot 7 \mathrm{H}_{2} \mathrm{O}\right)$ in the irrigation water.

It was verified that the tomatoes selected by treatment did not have damage and were of a homogeneous size. They were harvested as full red according to the USDA scale: red indicates that more than 90 percent of the surface in the aggregate shows a red color [27]. Quality analysis, biochemical analysis, and an arsenic content determination were performed on these fruits. 


\subsection{Fruit Quality}

The parameters that describe a fruit's quality (hydrogen potential (pH), total soluble solids (TSS), fruit firmness, titratable acidity (TA), electrical conductivity (EC), and Oxide-Reduction Potential (ORP) were determined, as described in López-Vargas et al. [28]. For this, six fruits per treatment (one per plant) of uniform size and in a light red state of maturity were collected from the third cluster.

\subsection{Biochemical Analysis}

The fruit samples were stored at $-80{ }^{\circ} \mathrm{C}$ until use. The samples were lyophilized (lyophilizer, Yamato Scientific Co. Ltd., Model D401, Santa Clara, CA, USA). For antioxidant compound determination, $200 \mathrm{mg}$ of lyophilized fruits and $20 \mathrm{mg}$ of polyvinylpyrrolidone were weighed. After this, $1.5 \mathrm{~mL}$ of phosphate buffer with a $\mathrm{pH}$ of 7-7.2 $(0.1 \mathrm{M})$ was added, and the mixture was then subjected to micro-centrifugation at $12,000 \mathrm{rpm}$ for $10 \mathrm{~min}$ at $4{ }^{\circ} \mathrm{C}$. The supernatant was filtered with a nylon membrane. With this extract proteins, glutathione and ABTS (2,2'-azino-bis[3-ethylbenzthiazolin-6-sulfonic acid]) antioxidant capacity in hydrophilic compounds were determined.

The quantification of total protein ( $\mathrm{mg} \mathrm{g}^{-1}$ of dry weight (DW)) was performed using Bradford's colorimetric technique [29]. In a microplate, $5 \mu \mathrm{L}$ of the extract and $250 \mu \mathrm{L}$ of Bradford reagent were placed in each well. The mixture was incubated for $10 \mathrm{~min}$ at room temperature $\left(26^{\circ} \mathrm{C}\right)$ and then read at a wavelength of $630 \mathrm{~nm}$ on a microplate reader (Allsheng, AMR-100 model, Hangzhou, China).

Lycopene and $\beta$-carotene (mg $\left.100 \mathrm{~g}^{-1} \mathrm{DW}\right)$ were determined according to Nagata and Yamashita [30]. For this, a sample $(0.1 \mathrm{~g})$ was mixed with $20 \mathrm{~mL}$ of hexane:acetone solution $(3: 2)$. An aliquot was taken from the supernatant and measured at absorbance values of 453, 505, 645, and $663 \mathrm{~nm}$, as shown in Equations (1) and (2).

$$
\begin{gathered}
\text { Lycopene }=-0.0458 \times \mathrm{Abs}_{663}+0.204 \times \mathrm{Abs}_{645}+0.372 \times \mathrm{Abs}_{505}-0.0806 \times \mathrm{Abs}_{453} \\
\beta \text {-carotene }=0.216 \times \mathrm{Abs}_{663}-1.22 \times \mathrm{Abs}_{645}-0.304 \times \mathrm{Abs}_{505}+0.452 \times \mathrm{Abs}_{453}
\end{gathered}
$$

Vitamin C ( $\left.\mathrm{mg} \mathrm{g}^{-1} \mathrm{DW}\right)$ was determined by the colorimetric method using 2,6 dichlorophenol, $1 \mathrm{~g}$ of fresh tissue, and $1 \mathrm{~mL}$ of $1 \%$ metaphosphoric acid and filtered with Whatman No. 1 filter paper, as described in Hung and Yeng [31].

Glutathione (mmol $100 \mathrm{~g}^{-1} \mathrm{DW}$ ) was determined using the method of Xue et al. [32] by means of a 5,5-dithio-bis-2 nitrobenzoic acid (DTNB) reaction. A mixture of $0.480 \mathrm{~mL}$ of the extract, $2.2 \mathrm{~mL}$ of sodium dibasic phosphate $\left(\mathrm{Na}_{2} \mathrm{HPO}_{4}\right.$ at $\left.0.32 \mathrm{M}\right)$, and $0.32 \mathrm{~mL}$ of the DTNB dye $(1 \mathrm{mM})$ was placed in a test tube. Then, the mixture was vortexed and read on a UV-Vis spectrophotometer (UNICO Spectrophotometer Model UV2150, Dayton, NJ, USA) at $412 \mathrm{~nm}$ using a quartz cell.

Flavonoids (mg $100 \mathrm{~g}^{-1} \mathrm{DW}$ ) were determined by the method of Arvouet-Grand et al. [33]. For the extraction, $100 \mathrm{mg}$ of lyophilized tissue was placed in a test tube with $10 \mathrm{~mL}$ of reagent-grade methanol and then shaken for $30 \mathrm{~s}$ until the mixture was homogenized. The mixture was filtered using No. 1 Whatman paper. For the quantification, $2 \mathrm{~mL}$ of the extract and $2 \mathrm{~mL}$ of a methanolic solution of aluminum trichloride $\left(\mathrm{AlCl}_{3}\right) 2 \%$ were added to the test tube and the mixture was left to rest for $20 \mathrm{~min}$ in the dark. The reading was then taken using a UV-Vis spectrophotometer (UNICO Spectrophotometer Model UV2150, Dayton, NJ, USA) at a wavelength of $415 \mathrm{~nm}$ using a quartz cell.

Phenols ( $\left.\mathrm{mg} \mathrm{g}^{-1} \mathrm{DW}\right)$ were determined with Folin-Ciocalteu reagent, as described in Cumplido-Nájera et al. [34]. The sample $(0.2 \mathrm{~g})$ was extracted with $1 \mathrm{~mL}$ of a water:acetone solution (1:1). The mixture was vortexed for $30 \mathrm{~s}$. The tubes were centrifuged (UNICO Spectrophotometer Model UV2150, Dayton, NJ, USA) at $17,500 \times g$ for $10 \mathrm{~min}$ at $4{ }^{\circ} \mathrm{C}$. In a test tube, $50 \mu \mathrm{L}$ of the supernatant, 200 $\mu \mathrm{L}$ of the Folin-Ciocalteu reagent, $500 \mu \mathrm{L}$ of $20 \%$ sodium carbonate $\left(\mathrm{Na}_{2} \mathrm{CO}_{3}\right)$, and $5 \mathrm{~mL}$ of distilled water were added, and the mixture was then vortexed for $30 \mathrm{~s}$. The samples were placed in a water 
bath at $45{ }^{\circ} \mathrm{C}$ for $30 \mathrm{~min}$. Finally, the reading was taken at an absorbance of $750 \mathrm{~nm}$ using a plastic cell in a UV-Vis spectrophotometer (UNICO Spectrophotometer Model UV2150, Dayton, NJ, USA).

The antioxidant activity by ABTS was determined using the spectrophotometric method of Re et al. [35], which is based on the discoloration of the ABTS radical cation. This radical was obtained from the reaction of ABTS at $7 \mathrm{mM}$ with potassium persulfate at $2.45 \mathrm{mM}(1: 1)$ in the dark at $26{ }^{\circ} \mathrm{C}$ for $16 \mathrm{~h}$ and then diluted with $20 \%$ ethanol to obtain an absorbance of $0.7 \pm 0.01$ at $750 \mathrm{~nm}$. Afterwards, to determine antioxidant capacity in the hydrophilic compounds, phosphate buffer, $5 \mu \mathrm{L}$ of extract, and $245 \mu \mathrm{L}$ of the ABTS radical dilution $(7 \mathrm{mM})$ were placed in a microplate, stirred for $5 \mathrm{~s}$ and then allowed to stand for $7 \mathrm{~min}$ in darkness. The absorbance was measured by a microplate reader (Allsheng, AMR-100 model, Hangzhou, China) at a wavelength of $750 \mathrm{~nm}$. The blank was prepared with $250 \mu \mathrm{L}$ of phosphate buffer (pH 7.0-7.2, 0.1 M). For the determination of the same in lipophilic compounds, extraction was carried out with a hexane:acetone solution. The results were expressed as vitamin $\mathrm{C}$ equivalents in $\mathrm{mg}$ per gram of dry weight $\left(\mathrm{mg} \mathrm{g}^{-1} \mathrm{DW}\right)$.

Hydrogen peroxide ( $\mu \mathrm{mol} \mathrm{g}{ }^{-1} \mathrm{DW}$ ) levels were determined according to Velikova et al. [36] with slight modifications; $25 \mathrm{mg}$ of lyophilized fruit tissue was weighed and placed in an Eppendorf tube, and $1 \mathrm{~mL}$ of cold $0.1 \%$ trichloroacetic acid was then added. The mixture was then centrifuged at $12,000 \times \mathrm{g}$ for $15 \mathrm{~min}$ and $0.5 \mathrm{~mL}$ of the supernatant was taken; $0.5 \mathrm{~mL}$ of $10 \mathrm{mM}$ potassium phosphate buffer ( $\mathrm{pH} 7.0)$ and $1 \mathrm{~mL}$ of $1 \mathrm{M}$ potassium iodide was added, and the reading was performed in a UV-Vis spectrophotometer (UNICO Spectrophotometer Model UV2150, Dayton, NJ, USA) at $390 \mathrm{~nm}$. The $\mathrm{H}_{2} \mathrm{O}_{2}$ content was measured using a standard curve.

\subsection{Arsenic Determination}

To quantify the arsenic content in the organs of the plant (Root, stem, leaf and fruit), two methods were performed. The method for X-ray fluorescence with miniaturized tubes (ThermoScientific Niton XLt3, Boston, MA, USA) was used in all organs of the plant. The detection capacity of the equipment is $2 \mu \mathrm{g} \mathrm{g}^{-1}$. Analyses were performed in triplicate. The second method was used only in fruit-for this, acid digestion was performed with $\mathrm{HNO}_{3}: \mathrm{H}_{2} \mathrm{O}_{2}$. Subsequently, the samples were analyzed by inductively coupled plasma optical emission spectrophotometry ICP-OES (Varian Agilent 730-ES, Santa Clara, CA, USA). The arsenic detection capacity by the equipment is $1 \mu \mathrm{g} \mathrm{\textrm {L } ^ { - 1 }}$.

\subsection{Statistical Analysis}

Six repetitions per treatment were analyzed, considering a fruit as an experimental unit. An analysis of variance (two-way ANOVA) was performed considering a completely randomized experimental design, and Fisher's Least Significant Difference test was applied to compare the means $(p \leq 0.05)$. Additionally, Pearson's correlation analysis was performed. The whole process was carried out using Infostat software (2018v) (https://www.infostat.com.ar).

\section{Results}

\subsection{Arsenic Determination}

The X-ray fluorescence analysis showed the accumulation of arsenic only in the root, stem and leaves of tomato plants; however, in fruits, it was not detected by either of the two methods used (Figure 1). Therefore, it is possible that the arsenic has not been translocated to the fruits, or that it has been translocated in negligible amounts. 


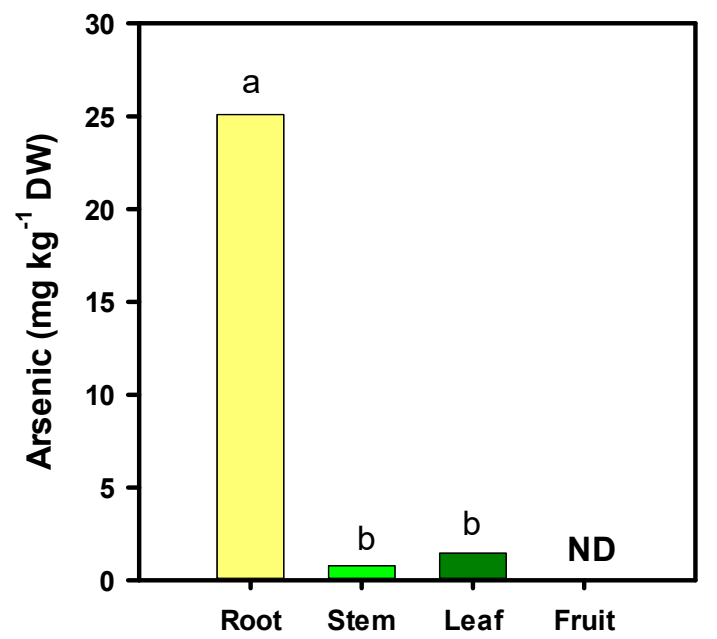

Figure 1. Arsenic concentration in different organs of the tomato plant. Different letters indicate significant differences according to Fisher's Least Significant Difference test $(p \leq 0.05)$. ND: Not detected.

\subsection{Fruit Quality}

The quality of tomato fruits exposed to As and $\mathrm{SiO}_{2} \mathrm{NPs}$ showed significant differences (Table 1). The firmness increased by $34.34 \%$ in the treatment with $1.6 \mathrm{mg} \mathrm{L}^{-1}$ of As and $250 \mathrm{mg} \mathrm{L}^{-1}$ of $\mathrm{SiO}_{2}$ NPs with respect to the control, although they were not statistically different. Regarding total soluble solids, there was a slight increase of $5.76 \%$ compared to the control with the treatment of $250 \mathrm{mg} \mathrm{L}^{-1}$ of $\mathrm{SiO}_{2} \mathrm{NPs}$, and also with $0.4 \mathrm{mg} \mathrm{L}^{-1}$ of As in the interaction with $1000 \mathrm{mg} \mathrm{L}^{-1}$ of $\mathrm{SiO}_{2} \mathrm{NPs}_{\text {. However, }}$ none of the treatments were statistically different. On the other hand, the $\mathrm{pH}$ decreased according to the exposure of As and $\mathrm{SiO}_{2} \mathrm{NPs}$ alone and when they interacted, the control had the highest $\mathrm{pH}$.

Table 1. Quality of tomato fruits with applications of $\mathrm{SiO}_{2}$ nanoparticles (NPs) and stressed by arsenic.

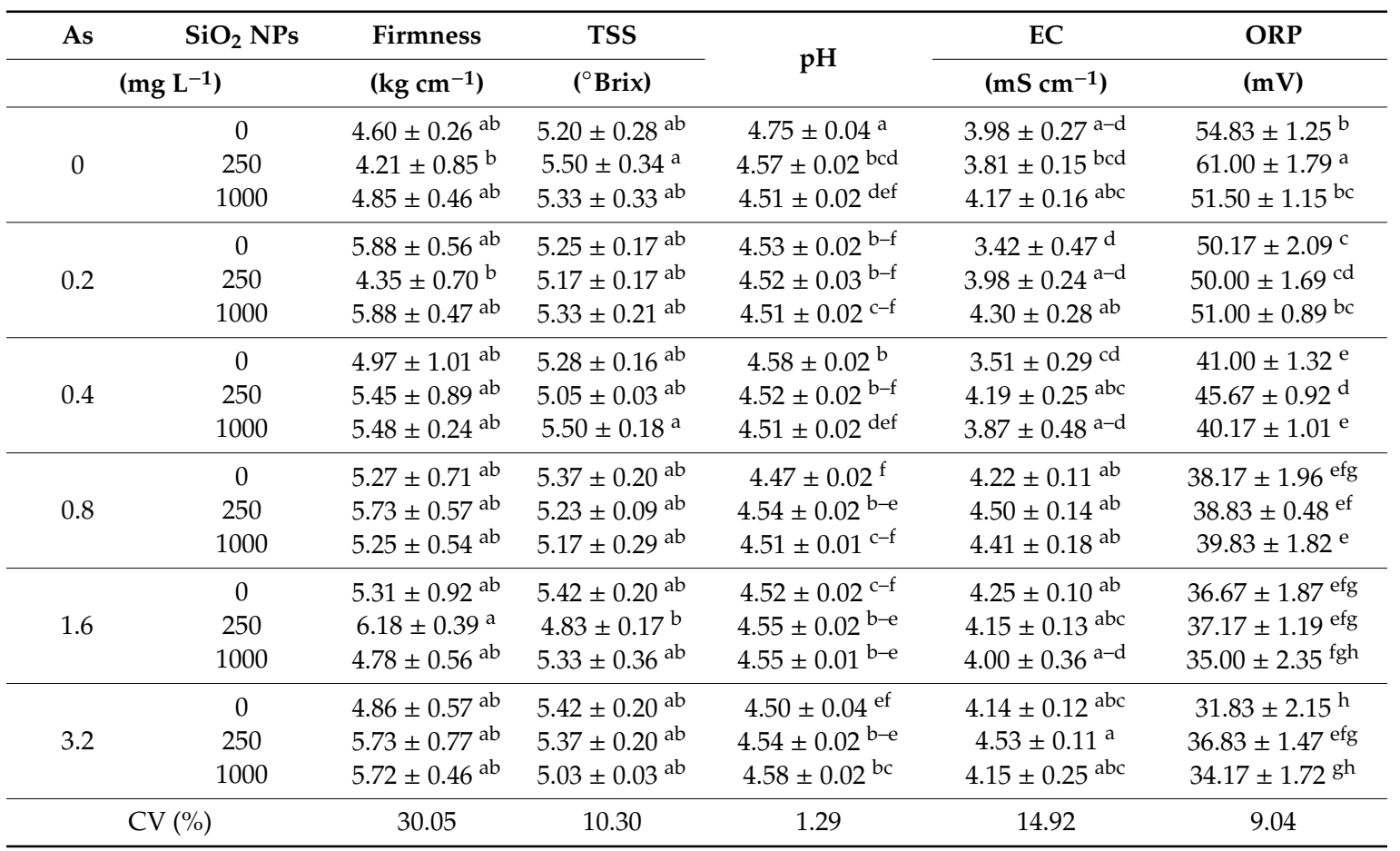

As: arsenic; TSS: Total soluble solids; pH: Hydrogen potential; EC: Electric conductivity; ORP: oxidation reduction potential; CV: Coefficient of variation. Different letters within a column indicate significant differences according to Fisher's Least Significant Difference test $(p \leq 0.05)$. 
A tendency to increase the EC was observed at high doses of As, and in the interaction with the $\mathrm{NPs}$, the treatment with $3.2 \mathrm{As}$ and $250 \mathrm{SiO}_{2} \mathrm{NPs} \mathrm{mg} \mathrm{L}^{-1}$ resulted in an increase of $13.8 \%$, while the low dose of As $\left(0.2 \mathrm{mg} \mathrm{L}^{-1}\right)$ showed a decrease $(-4.07 \%)$ compared to the control, although they were not statistically different. Regarding the ORP, a decreasing tendency was observed as arsenic and $\mathrm{SiO}_{2}$ NPs were applied; the dose of $3.2 \mathrm{mg} \mathrm{L}^{-1}$ of As decreased the ORP by $72.25 \%$.

\subsection{Proteins}

Total proteins decreased due to the interaction of the highest dose of $\mathrm{As}$ and $\mathrm{SiO}_{2} \mathrm{NPs}$, reaching up to $31.16 \%$ and $22.09 \%$ with $3.2-250$ or $1000 \mathrm{mg} \mathrm{L}^{-1}$ of As and Si NPs, respectively, although the

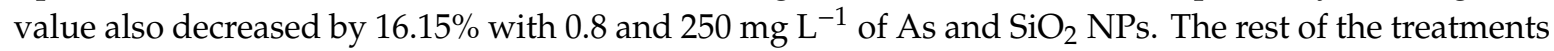
were not statistically different from the control (Figure 2).

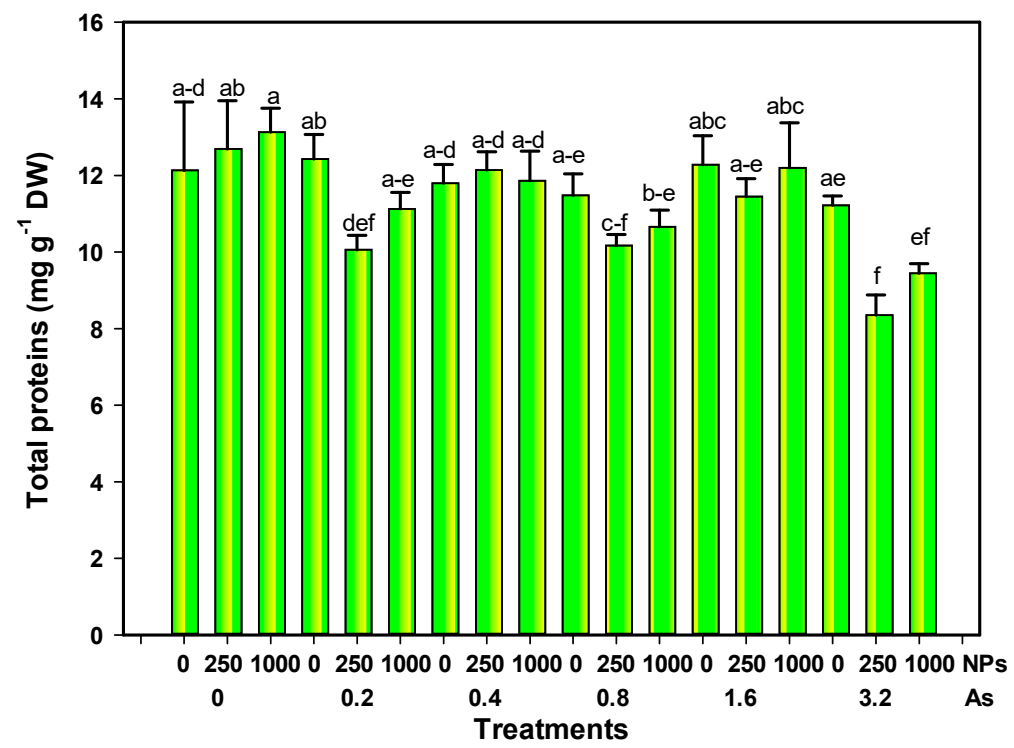

Figure 2. Total proteins in tomato fruits exposed to different doses of arsenic and nanoparticles. Different letters above the bars indicate significant differences according to Fisher's Least Significant Difference test $(p \leq 0.05)$. NPs: Dose applied of $\mathrm{SiO}_{2} \mathrm{NPs}\left(\mathrm{mg} \mathrm{L}^{-1}\right)$; As: Dose applied of arsenic $\left(\mathrm{mg} \mathrm{L}^{-1}\right)$.

\subsection{Antioxidant Compounds}

The lycopene content in tomato fruits increased by $34 \%$ at the lowest dose of As $\left(0.2 \mathrm{mg} \mathrm{L}^{-1}\right)$. As- $-\mathrm{SiO}_{2} \mathrm{NP}$ interactions at 3.2-1000 $\mathrm{mg} \mathrm{L}^{-1}$ increased lycopene by $40.82 \% . \mathrm{SiO}_{2} \mathrm{NPs}$ at $250 \mathrm{mg} \mathrm{L}^{-1}$ reduced the lycopene content by $51.30 \%$, and 0.2 and $1000 \mathrm{mg} \mathrm{L}^{-1}$ of $\mathrm{As}-\mathrm{SiO}_{2} \mathrm{NPs}$ decreased it by $51.88 \%$ (Figure $3 \mathrm{~A}$ ).

Regarding the content of $\beta$-carotene, there was an increase with exposure to doses of $0.2,0.8$, and $3.2 \mathrm{mg} \mathrm{L}^{-1}$ of As without application of $\mathrm{SiO}_{2} \mathrm{NPs}(29,49$, and $18 \%$, respectively). An amount of $250 \mathrm{mg} \mathrm{L}^{-1}$ of $\mathrm{SiO}_{2} \mathrm{NPs}$ decreased the content by $24 \%$, although it was not statistically different from the control. The interaction between 3.2 and $250 \mathrm{mg} \mathrm{L}^{-1} \mathrm{As}-\mathrm{SiO}_{2} \mathrm{NPs}$ decreased the $\beta$-carotene content by $40 \%$. However, the dose of $1000 \mathrm{mg} \mathrm{L}^{-1}$ of $\mathrm{SiO}_{2} \mathrm{NPs}$ without As increased the content of $\beta$-carotene by $13 \%$ (Figure 3B). 

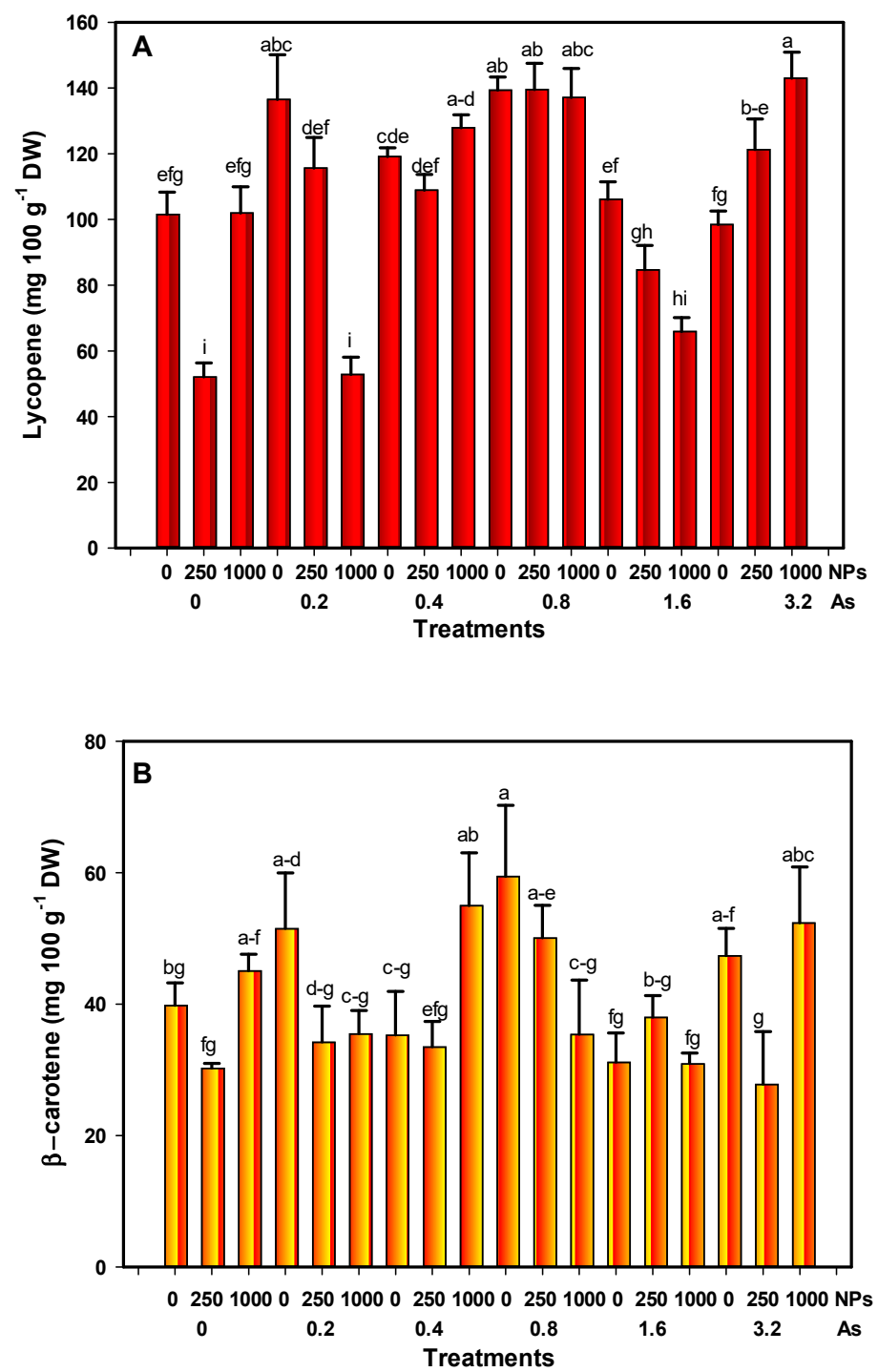

Figure 3. (A) Lycopene and (B) $\beta$-carotene content in fruits under stress conditions. Different letters above the bars indicate significant differences according to Fisher's Least Significant Difference test $(p \leq 0.05)$. NPs: Dose applied of $\mathrm{SiO}_{2} \mathrm{NPs}\left(\mathrm{mg} \mathrm{L}^{-1}\right)$; As: Dose applied of arsenic $\left(\mathrm{mg} \mathrm{L}^{-1}\right)$.

Glutathione increased with the application of $250 \mathrm{mg} \mathrm{L}^{-1}$ of $\mathrm{SiO}_{2} \mathrm{NPs}(35.48 \%)$; however, this dose in combination with 0.2 and $0.8 \mathrm{mg} \mathrm{L}^{-1}$ of As decreased glutathione by $32.26 \%$ and $35.49 \%$, respectively. The application of $0.8 \mathrm{mg} \mathrm{L}^{-1}$ of As decreased glutathione by $45.15 \%$. When the plants were exposed to the two high doses of As and with the interaction with $\mathrm{SiO}_{2} \mathrm{NPs}$, there was a significant increase in glutathione with respect to the control. However, the greatest increase $(45.16 \%)$ was in response to $3.2 \mathrm{mg} \mathrm{L}^{-1}$ of As without NPs, and $41.13 \%$ with $1.6-250 \mathrm{mg} \mathrm{L}^{-1}$ of As- $\mathrm{SiO}_{2} \mathrm{NPs}_{\text {(Figure } 4 \mathrm{~A} \text { ). }}$.

Regarding the vitamin C content, there was a $31.09 \%$ decrease when $250 \mathrm{mg} \mathrm{L}^{-1}$ of $\mathrm{SiO}_{2} \mathrm{NPs}_{\text {was }}$ applied. In addition, the three highest doses of As $\left(0.8,1.6\right.$, and $\left.3.2 \mathrm{mg} \mathrm{L}^{-1}\right)$ alone and in combination with the $\mathrm{SiO}_{2} \mathrm{NPs}$ decreased the vitamin $\mathrm{C}$ content. The treatment of $0.8-250 \mathrm{mg} \mathrm{L}^{-1}$ of $\mathrm{As}_{-} \mathrm{SiO}_{2} \mathrm{NPs}$ showed a $45.22 \%$ reduction in vitamin $C$, while treatments consisting of 1.6 and $3.2 \mathrm{mg} \mathrm{L}^{-1}$ of As in combination with $1000 \mathrm{mg} \mathrm{L}^{-1}$ of $\mathrm{SiO}_{2} \mathrm{NPs}$ resulted in decreases of $42.02 \%$ and $36.04 \%$, respectively. Although the doses of 0.2 and $0.4 \mathrm{mg} \mathrm{L}^{-1}$ of As alone showed a slight increase in this compound $(8.12 \%$ and $9.54 \%$, respectively), they were not statistically different from the control (Figure 4B). 

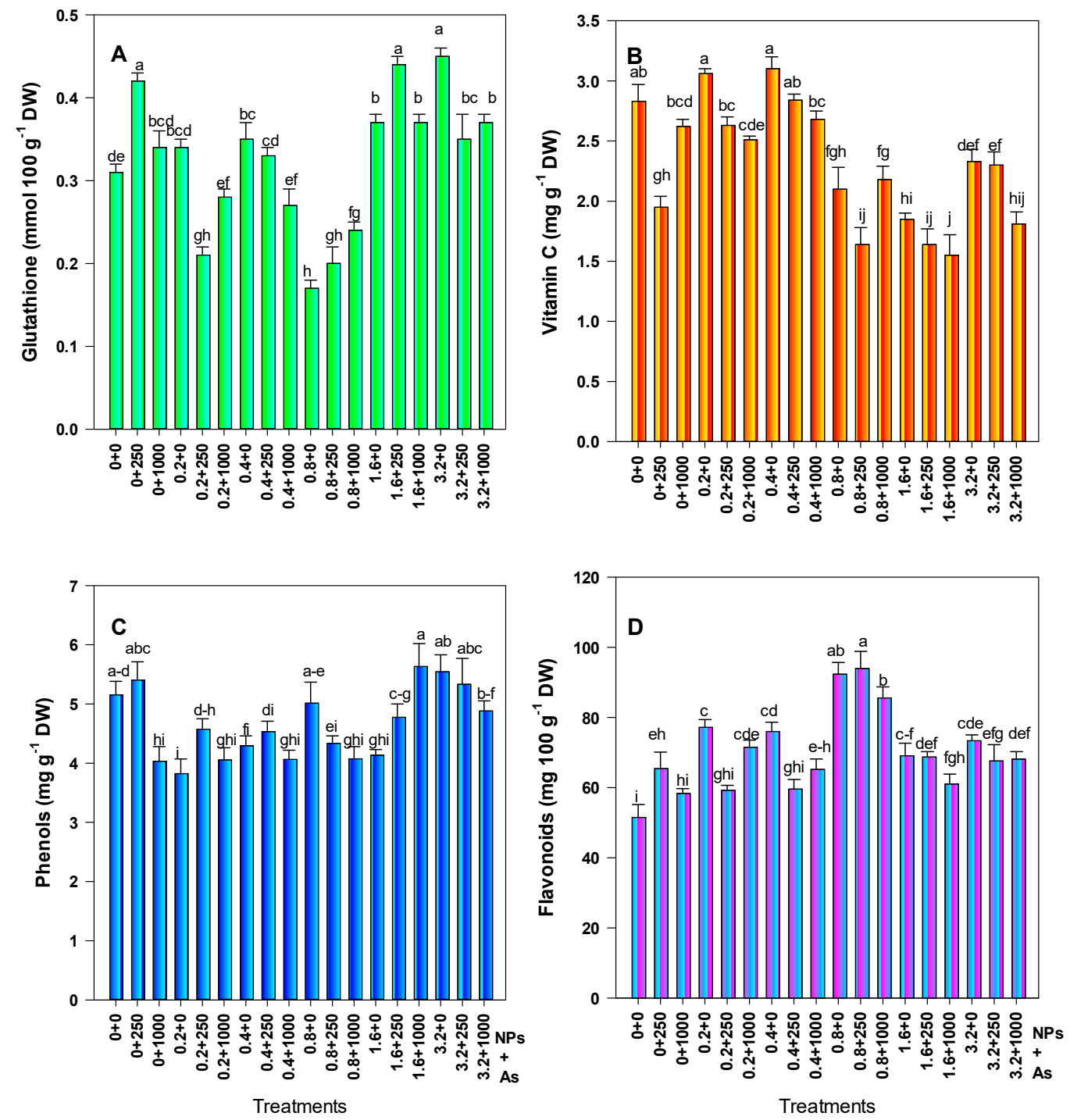

Figure 4. Non-enzymatic antioxidant compounds in tomato fruits. (A) Glutathione, (B) Vitamin C, (C) Phenols, and (D) Flavonoids. Different letters above the bars indicate significant differences according to Fisher's Least Significant Difference test $(p \leq 0.05)$. NPs: Dose applied of $\mathrm{SiO}_{2} \mathrm{NPs}$ $\left(\mathrm{mg} \mathrm{L}^{-1}\right)$; As: Dose applied of arsenic $\left(\mathrm{mg} \mathrm{L}^{-1}\right)$.

Phenols decreased with low doses of As alone, as well as in combination with $\mathrm{SiO}_{2} \mathrm{NPs}$. The treatments with the greatest decrease in phenols were $0.2 \mathrm{mg} \mathrm{L}^{-1}$ of As $(25.82 \%)$, as well as 0.2 and $0.4 \mathrm{mg} \mathrm{L}^{-1}$ in combination with $1000 \mathrm{mg} \mathrm{L}^{-1}$ of $\mathrm{SiO}_{2} \mathrm{NPs}(21.35 \%$ and $21.16 \%$, respectively). Regarding the effect of the $\mathrm{SiO}_{2} \mathrm{NPs}$, the dose of $250 \mathrm{mg} \mathrm{L}^{-1}$ showed a slight increase (4.85\%); however, it was statistically the same as the control. In contrast, $1000 \mathrm{mg} \mathrm{L}^{-1}$ of $\mathrm{SiO}_{2} \mathrm{NPs}$ decreased the phenol content by $21.74 \%$ (Figure $4 \mathrm{C}$ ).

Flavonoids increased upon exposure to As and $\mathrm{SiO}_{2} \mathrm{NPs}$, although treatments with $1000 \mathrm{mg} \mathrm{L}^{-1}$ of $\mathrm{SiO}_{2} \mathrm{NPs}$ alone, as well as 0.2 and $0.4 \mathrm{mg} \mathrm{L}^{-1}$ of As in combination with $250 \mathrm{mg} \mathrm{L}^{-1} \mathrm{SiO}_{2} \mathrm{NPs}_{\text {sere }}$ statistically the same as the control The greatest increase in flavonoids was with $0.8 \mathrm{mg} \mathrm{L}^{-1}$ of As alone, and in combination with $250 \mathrm{mg} \mathrm{L}^{-1}$ of $\mathrm{SiO}_{2} \mathrm{NPs}$ - up to $79.26 \%$ and $82.42 \%$, respectively (Figure 4D).

\subsection{Antioxidant Capacity}

The antioxidant capacity determined in tomato fruits showed significant differences between treatments (Figure 5). With respect to hydrophilic compounds, 3.2-1000 and $1.6-250 \mathrm{mg} \mathrm{L}^{-1}$ of 
As $-\mathrm{SiO}_{2} \mathrm{NPs}$ showed an increase of $35.14 \%$ and $20.54 \%$, respectively. However, the antioxidant capacity decreased with $0.2-250 \mathrm{mg} \mathrm{L}^{-1} \mathrm{As}-\mathrm{SiO}_{2} \mathrm{NPs}$ - by up to $34.4 \%$. On the other hand, lipophilic compounds showed a similar trend to hydrophilic compounds; the highest dose of As $\left(3.2 \mathrm{mg} \mathrm{L}^{-1}\right)$ in combination with 250 and $1000 \mathrm{mg} \mathrm{L}^{-1}$ of $\mathrm{SiO}_{2}$ NPs being the treatments that presented respective increases of up to $104.24 \%$ and $121.20 \%$ in terms of antioxidant capacity.
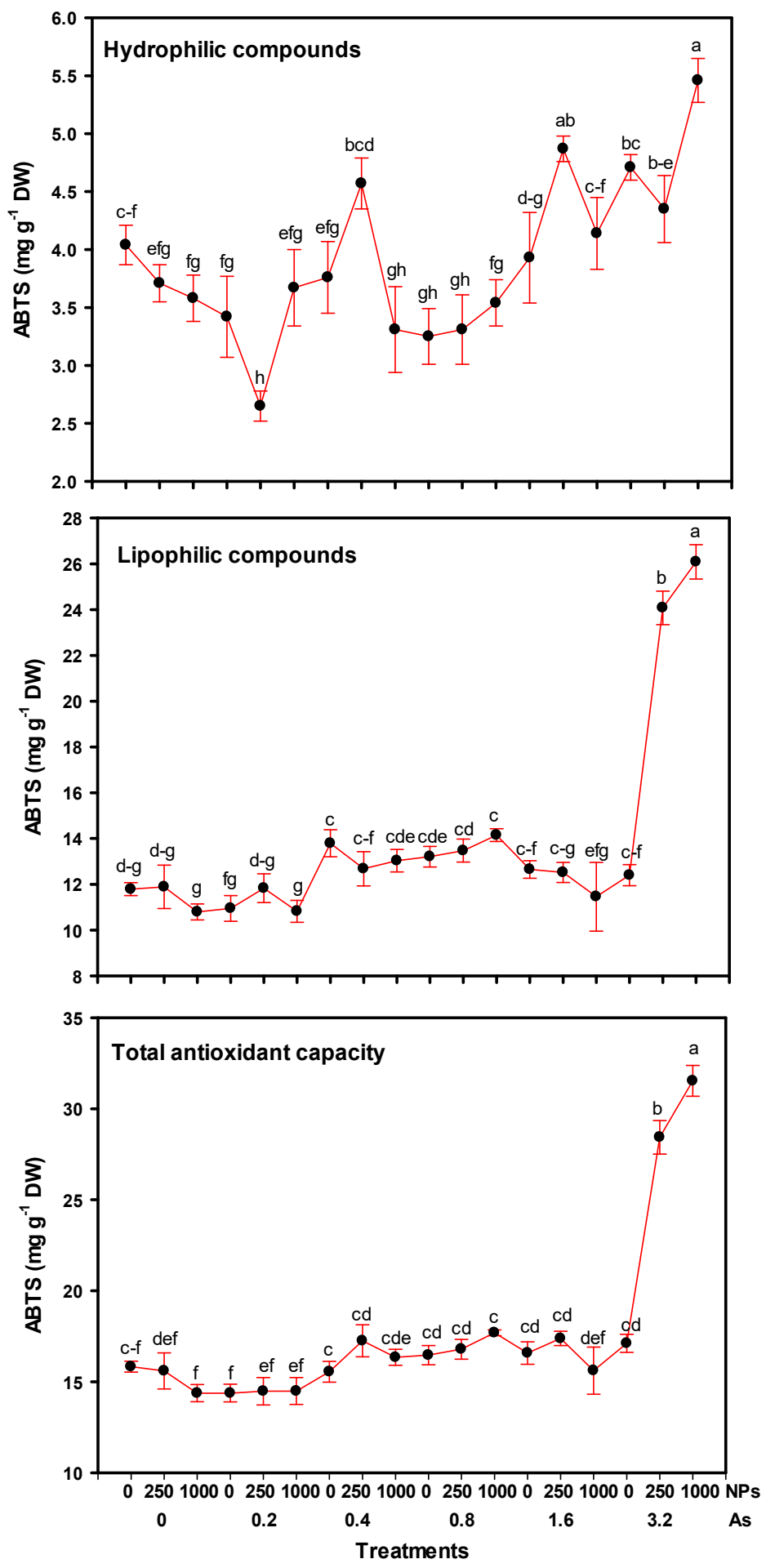

Figure 5. Antioxidant capacity of tomato fruits with applications of $\mathrm{SiO}_{2} \mathrm{NPs}$ and stressed by arsenic. Different letters indicate significant differences according to Fisher's Least Significant Difference test $(p \leq 0.05)$. NPs: Dose applied of $\mathrm{SiO}_{2} \mathrm{NPs}\left(\mathrm{mg} \mathrm{L}^{-1}\right)$; As: Dose applied of arsenic $\left(\mathrm{mg} \mathrm{L}^{-1}\right)$. 
Regarding the total antioxidant capacity, the highest dose of arsenic in combination with both doses of $\mathrm{SiO}_{2} \mathrm{NPs}$ had the highest values, being $79.59 \%$ and $99.17 \%$ higher than the control, respectively.

\subsection{Hydrogen Peroxide Content}

The $\mathrm{H}_{2} \mathrm{O}_{2}$ level increased by $46.15 \%$ with $250 \mathrm{mg} \mathrm{L}^{-1}$ of $\mathrm{SiO}_{2} \mathrm{NPs}$; however, it decreased by $17.05 \%$ with $1000 \mathrm{mg} \mathrm{L}^{-1}$ of $\mathrm{SiO}_{2} \mathrm{NPs}$ compared with the control. On the other hand, $0.8 \mathrm{mg} \mathrm{L}^{-1}$ of arsenic alone increased the $\mathrm{H}_{2} \mathrm{O}_{2}$ level by $31.31 \%$. Moreover, the interaction of $0.2 \mathrm{mg} \mathrm{L}^{-1}$ of As with 250 and $1000 \mathrm{mg} \mathrm{L}^{-1}$ of $\mathrm{SiO}_{2} \mathrm{NPs}$ showed a slight increase of $15.93 \%$ and $26.92 \%$, respectively (Figure 6).

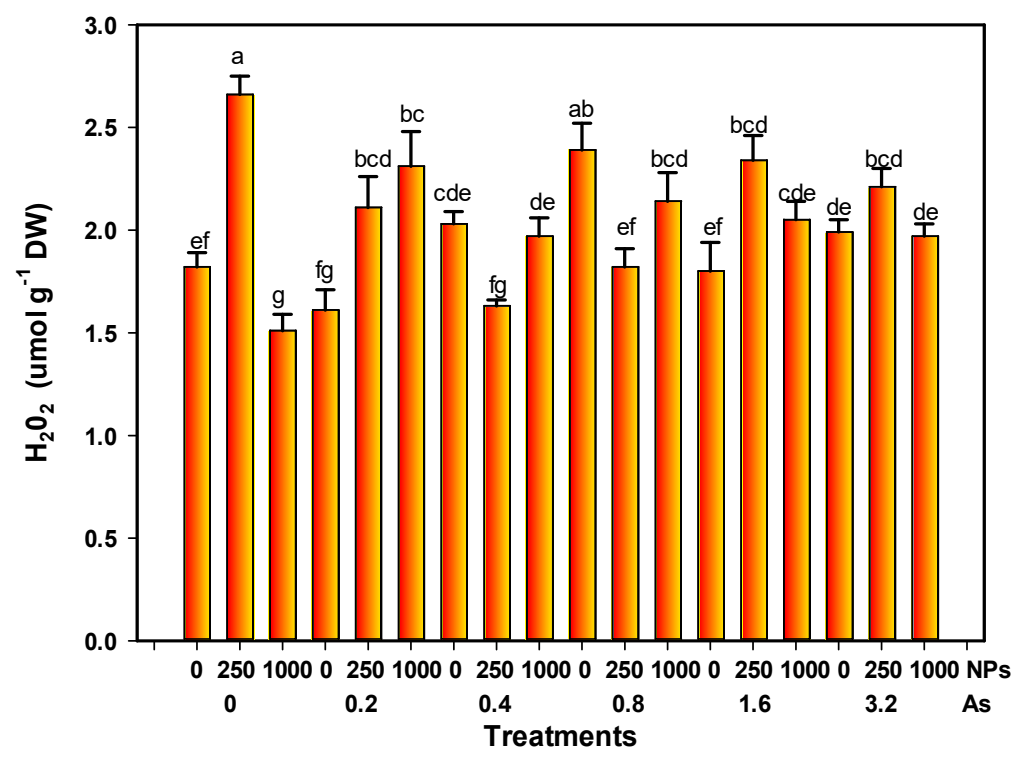

Figure 6. $\mathrm{H}_{2} \mathrm{O}_{2}$ content of tomato fruits with application of $\mathrm{SiO}_{2} \mathrm{NPs}$ and stressed by arsenic. Different letters above the columns indicate significant differences according to Fisher's Least Significant Difference test $(p \leq 0.05)$. NPs: Dose applied of $\mathrm{SiO}_{2} \mathrm{NPs}\left(\mathrm{mg} \mathrm{L}^{-1}\right)$; As: Dose applied of arsenic $\left(\mathrm{mg} \mathrm{L}^{-1}\right)$.

Regarding the correlation between the different compounds evaluated, the results of the Pearson test showed high correlations between some variables, and only the $\mathrm{SiO}_{2} \mathrm{NPs}$ did not show a correlation with any variable (Table 2). A positive correlation of As was observed with the antioxidant capacity of hydrophilic, lipophilic, total, and glutathione compounds $(r=0.53,0.67,0.71$, and $0.41(p \leq 0.01)$, respectively); however, As had a negative correlation with proteins, vitamin C and ORP $(r=-0.35$ $(p \leq 0.05),-0.42$, and $-0.71(p \leq 0.01))$. This suggests that arsenic is the treatment that most strongly influences the antioxidant content of the tomato fruits.

It was observed that the total antioxidant capacity had a highly positive correlation with the antioxidant capacity of lipophilic compounds $(r=0.99, p \leq 0.01)$, while it was negatively correlated with proteins $(r=-0.41, p \leq 0.01)$ and ORP $(r=-0.40, p \leq 0.01)$.

Lycopene showed a positive correlation with the antioxidant capacity of lipophilic compounds $(r=0.33, p \leq 0.05)$ and with the content of flavonoids $(r=0.39, p \leq 0.01)$, while glutathione was positively correlated with the antioxidant capacity of hydrophilic compounds $(r=0.52, p \leq 0.01)$. Likewise, it was observed that there was a negative correlation between lycopene and glutathione $(r=-0.37, p \leq 0.05)$.

Finally, the ORP had a negative correlation with the antioxidant capacity of hydrophilic compounds $(r=-0.27, p \leq 0.05)$, the antioxidant capacity of lipophilic compounds $(r=-0.38, p \leq 0.01)$, the total antioxidant capacity $(r=-0.40, p \leq 0.01)$, lycopene $(r=-0.28, p \leq 0.05)$, and flavonoids $(r=-0.33$, $p \leq 0.05)$; in contrast, it presented a positive correlation with proteins $(r=0.22, p \leq 0.05)$ and vitamin $C$ $(r=0.38, p \leq 0.01)$. 
Table 2. Pearson correlations between $\mathrm{As}, \mathrm{SiO}_{2} \mathrm{NPs}$, antioxidant capacity, $\mathrm{H}_{2} \mathrm{O}_{2}$, antioxidant compounds, proteins and ORP.

\begin{tabular}{|c|c|c|c|c|c|c|c|c|c|c|c|c|}
\hline & ABTS H & ABTS L & TAC ABTS & $\mathrm{H}_{2} \mathrm{O}_{2}$ & Lycopene & B-Carotene & Proteins & Vitamin C & Glutathione & Phenols & Flavonoids & ORP \\
\hline As & $0.53^{* *}$ & $0.67^{* *}$ & $0.71^{* *}$ & 0.08 NS & 0.14 NS & $-0.02 \mathrm{NS}$ & $-0.35^{*}$ & $-0.42^{* *}$ & $0.41^{* *}$ & $0.35 *$ & $0.08 \mathrm{NS}$ & -0.71 ** \\
\hline $\mathrm{SiO}_{2} \mathrm{NPs}$ & $0.04 \mathrm{NS}$ & $0.14 \mathrm{NS}$ & $0.14 \mathrm{NS}$ & $-0.04 \mathrm{NS}$ & $-0.12 \mathrm{NS}$ & $0.02 \mathrm{NS}$ & $-0.04 \mathrm{NS}$ & $-0.18 \mathrm{NS}$ & $-0.11 \mathrm{NS}$ & $-0.14 \mathrm{NS}$ & $-0.13 \mathrm{NS}$ & -0.05 \\
\hline ABTS H & & 0.37 * & $0.53^{* *}$ & $0.04 \mathrm{NS}$ & $-0.08 \mathrm{NS}$ & $0.01 \mathrm{NS}$ & $0.10 \mathrm{NS}$ & $-0.19 \mathrm{NS}$ & $0.52 * *$ & $0.33^{*}$ & $-0.1 \mathrm{NS}$ & $-0.27^{*}$ \\
\hline ABTS L & & & $0.99 * *$ & $0.10 \mathrm{NS}$ & 0.33 * & $-0.03 \mathrm{NS}$ & $-0.46^{* *}$ & $-0.22 *$ & $0.07 \mathrm{NS}$ & $0.16 \mathrm{NS}$ & $0.04 \mathrm{NS}$ & $-0.38^{* *}$ \\
\hline TAC ABTS & & & & $0.10 \mathrm{NS}$ & $0.29 *$ & $-0.02 \mathrm{NS}$ & $-0.41^{* *}$ & -0.24 * & $0.16 \mathrm{NS}$ & 0.20 * & $0.02 \mathrm{NS}$ & $-0.40^{* *}$ \\
\hline $\mathrm{H}_{2} \mathrm{O}_{2}$ & & & & & $-0.22 *$ & $-0.15 \mathrm{NS}$ & $-0.04 \mathrm{NS}$ & $-0.21 *$ & $0.05 \mathrm{NS}$ & 0.31 * & $0.19 \mathrm{NS}$ & $0.02 \mathrm{NS}$ \\
\hline Lycopene & & & & & & $0.19 \mathrm{NS}$ & $-0.19 \mathrm{NS}$ & $0.17 \mathrm{NS}$ & $-0.37 *$ & $0.16 \mathrm{NS}$ & $0.39 * *$ & $-0.28 *$ \\
\hline$\beta$-carotene & & & & & & & $0.05 \mathrm{NS}$ & $-0.03 \mathrm{NS}$ & $-0.19 \mathrm{NS}$ & $0.01 \mathrm{NS}$ & 0.22 * & $-0.10 \mathrm{NS}$ \\
\hline Proteins & & & & & & & & $0.11 \mathrm{NS}$ & $0.18 \mathrm{NS}$ & $-0.06 \mathrm{NS}$ & $-0.04 \mathrm{NS}$ & 0.22 * \\
\hline Vitamin C & & & & & & & & & $-0.09 \mathrm{NS}$ & $-0.22 *$ & $0.17 \mathrm{NS}$ & $0.38^{* *}$ \\
\hline GSH & & & & & & & & & & 0.25 * & $-0.28^{*}$ & $0.11 \mathrm{NS}$ \\
\hline Phenols & & & & & & & & & & & $-0.07 \mathrm{NS}$ & $-0.12 \mathrm{NS}$ \\
\hline Flavonoids & & & & & & & & & & & & $-0.33^{*}$ \\
\hline
\end{tabular}

$*$ ** Significant correlation at the $p \leq 0.05$ and $\leq 0.01$ levels, respectively. NS: no significance. ABTS H: Antioxidant capacity determined in hydrophilic compounds by 2, ','-azino-bis[3-ethylbenzthiazolin-6-sulfonic acid] radical, ABTS L: Antioxidant capacity determined in lipophilic compounds by 2,2'-azino-bis[3-ethylbenzthiazolin-6-sulfonic acid] radical, As: arsenic, $\mathrm{SiO}_{2}$ NPs: nanoparticles, $\mathrm{H}_{2} \mathrm{O}_{2}$ : hydrogen peroxide, GSH: glutathione, and ORP: oxidation reduction potential. 


\section{Discussion}

Considering the quality and safety of food products, the determination of toxic elements such as arsenic is important, since food contaminated with this element can cause health risks [37]. In the present study, arsenic was not detected in tomato fruits that were exposed to different concentrations of this element. This is because arsenic accumulates mainly in the root, while only a small portion is translocated to shoots with even smaller quantities to fruits [38]. Several studies have shown the presence of arsenic in fruits at very low concentrations $[13,39,40]$, and so the risk for human consumption is very low.

The quality of fruits is indispensable for the market, particularly since fleshy fruits are perishable, and their quality is affected by different types of both abiotic and biotic stresses [41]. The observed effects are different depending on the variety, the phenological stage, the duration of stress, as well as the interaction with other environmental conditions [42]. The quality of the fruit is greatly modified during the ripening process in its different stages, affecting both the taste quality and the nutritional quality [43]. The initial decision to buy fruits and vegetables is usually made based on appearance and firmness [44]. In this sense, the firmness of the fruits increased consistently with the application of $\mathrm{SiO}_{2} \mathrm{NPs}$, coinciding with reports of other authors $[45,46]$. This is because silicon can accumulate in the epidermis, making it more rigid [47].

The application of $\mathrm{SiO}_{2} \mathrm{NPs}$ decreased the $\mathrm{pH}$ of tomato fruits, which coincides with what was observed in jalapeño pepper with the application of Cu NPs + Cs-PVA [48]. The $\mathrm{pH}$ of the fruits directly influences the quality, in addition to the fact that consumers prefer less acidic fruits because they have a better flavor [49]. As for TSS and EC, in some studies, there was a decrease or increase in these parameters, depending on the type of treatment or the conditions to which the fruits were exposed [50,51].

The decrease in ORP observed in the $\mathrm{As}-\mathrm{SiO}_{2} \mathrm{NPs}$ interaction indicates a better fruit quality, since it can translate into a higher antioxidant potential [52], as observed in the correlations in this work. This trend has been reported by other authors who have worked with the application of NPs in tomato [28] and observed a decrease in ORP of 5.7\% with the application of $250 \mathrm{mg} \mathrm{L}^{-1}$ of Cu NPs.

Proteins play an important role in regulating the development and quality of fruit [53]. Most of the regulatory proteins related to ripening in tomatoes have been functionally associated with the climacteric induction of ethylene biosynthesis [54]. Within all proteins, there are metallothioneins, which are proteins that respond to heavy metal stress [55]. Thiol groups in metallothioneins can act as powerful antioxidants, so they can play a role in protecting against oxidative damage [56]. However, when heavy metal concentrations are high, there is a higher generation of ROS, and therefore, greater oxidative stress [57], which can consequently decrease protein production. On the other hand, nanoparticles have been implicated in the increase in proteins in cucumber fruits [58]. However, they do not always have that effect, since it depends on the type of NPs and the dose used.

From the visual perspective, the quality of the fruit is directly related to the amount of carotenoids, mainly lycopene and $\beta$-carotene, that accumulate in ripe tomato fruits [59]. In addition, the consumption of carotenoids has beneficial effects on human health, since this can reduce the risk of certain forms of cancer, cardiovascular diseases, macular degeneration, among others [60]. In tomato fruits, ripening involves various morphological, physiological, biochemical, and molecular changes, including the degradation of chlorophyll as well as the synthesis and storage of carotenoids (mainly lycopene) during the transition from the chloroplast to the chromoplast [61]. Another important carotenoid is $\beta$-carotene, which is the main precursor of vitamin $A$; as opposed to $\beta$-carotene, lycopene has no pro-vitamin A activity but is a good antioxidant [62]. Lycopene is a powerful antioxidant and has a protective role against cancer [63]. In tomato fruits, the amount of lycopene can vary depending on the species, the stage of maturity, and the environmental conditions under which the fruit ripens [64]. The carotenoids in ripe fruit appear to play an important role in the detoxification of ROS, in particular to relieve the symptoms of stress induced by arsenic exposure [15], which is consistent with the results observed in this work. 
Reduced glutathione ( $\gamma$-glutamyl-cysteinyl glycine, GSH) participates in functional activities in many plants [65]. GSH has unique redox and nucleophilic properties and is involved in the cellular defense against the toxic actions of xenobiotics, oxiradicals, salinity, acidity, and metal cations [66]. Specifically under conditions of metal stress, GSH is a non-enzymatic antioxidant that plays a central role in homeostasis and acts as a precursor to a metal-binding peptide [67]. Therefore, a high concentration of GSH in cells acts as a buffer system against redox imbalance [68]. On the other hand, silicon can counteract the negative impact of oxidative stress by restricting the production of ROS caused by arsenic, in addition to improving the action of various antioxidant compounds and regulating the osmotic potential of the cell [69].

Vitamin $C$ has a main function as an antioxidant and cofactor in redox reactions, in addition to being involved in the activation of epigenetic mechanisms that control cell differentiation [70]. However, vitamin $C$ is highly unstable, and its levels may vary if subjected to stress factors [71]. Additionally, the antioxidants in the fruit can be affected by the intensity of light, temperature, and internal factors such as variety of cultivation, load, and position of the fruit [72]. For human health, sufficient absorption and distribution of vitamin $C$ throughout the body are essential for many biochemical processes, including some that are vital to the growth and spread of tumors [73].

Phenols are antioxidant compounds that trigger the synthesis of a series of secondary metabolites from the shikimic acid pathway or through phenylpropanoids under conditions of abiotic stress [74]. The antioxidant capacity of phenolic compounds is also attributed to their ability to chelate metal ions involved in the production of free radicals [75]. Phenolic compounds can act as antioxidants, since hydroxyl groups donate hydrogen and can react with reactive oxygen species in a termination reaction, which breaks the cycle of generating new radicals [76].

It is known that silicon promotes the production of phenolic compounds that have an antioxidant or structural role. In addition, it can improve toxicity to heavy metals such as aluminum [77].

Flavonoids are among the most abundant phytochemicals in fruits and vegetables and have cancer cell anti-proliferative, antioxidant, anti-inflammatory, and estrogenic activities [78]. Flavonoids have anticancer activity in cellular and preclinical animal models, which makes them potential candidates in cancer prevention and treatment [79]. This is due to their antioxidants, which regulate the homeostasis of ROS [80].

Antioxidant capacity represents the ability to inhibit the oxidation process. It is a very desirable property of food since it plays an important role in various diseases [81]. There are different methods to evaluate the antioxidant capacity of a food; the two most commonly used tests are ABTS (2,2'-azino-bis-(3-ethylbenzothiazoline-6-sulfonic acid) and DPPH (2,2-diphenyl-1-picrylhydrazyl) [82]. The ABTS test can react with a wider range of antioxidant compounds [83]. Since the ABTS test is based on the generation of blue/green ABTS ${ }^{\bullet+}$, which is applicable to both hydrophilic and lipophilic antioxidant systems, this method is better for the evaluation of the antioxidant capacity of highly pigmented and hydrophilic compounds compared to DPPH [84]. However, the antioxidant capacity of fruits to inhibit ABTS or DPPH also depends on the type of treatment to which they have been exposed [85].

ROS include free radicals, such as $\mathrm{O}^{2-}$ and $\mathrm{OH}$, and non-radicals, such as $\mathrm{H}_{2} \mathrm{O}_{2}$ and ${ }^{1} \mathrm{O}_{2}$, which induce oxidative damage in cells [86]. The increase in the $\mathrm{H}_{2} \mathrm{O}_{2}$ content is a typical plant response to arsenic exposure [87], so much so that when arsenic exposure increases, $\mathrm{H}_{2} \mathrm{O}_{2}$ levels also increase, being strongly time dependent [15]. One of the most prominent and earliest defense responses is the oxidative burst, generated by ROS, which includes $\mathrm{H}_{2} \mathrm{O}_{2}$ [88]. In addition to this, fruit ripening is an oxidative phenomenon that raises the level of ROS, a process that is genetically programmed [89]. Thus, the changes in the ROS of tomato fruits can be modified both by environmental and arsenic stress, as well as by the natural ripening process. 


\section{Conclusions}

The results obtained in this research study highlight the importance of the stressful effect that arsenic can have on tomato fruit and how it modifies the antioxidant compounds. Low doses of As $\left(0.2 \mathrm{mg} \mathrm{L}^{-1}\right)$ in irrigation water induce a greater accumulation of antioxidant compounds; however, when exposed to high doses or when they interact with $\mathrm{SiO}_{2} \mathrm{NPs}$, there appears to be greater stress and oxidative damage that inhibit these compounds. On the other hand, $250 \mathrm{mg} \mathrm{L}^{-1}$ of $\mathrm{SiO}_{2} \mathrm{NPs}$ increased glutathione. Flavonoids are the only group of antioxidants that are increased by As and $\mathrm{SiO}_{2} \mathrm{NPs}$. Total antioxidant capacity shows an increase with the highest dose of As in combination with $\mathrm{SiO}_{2} \mathrm{NPs}$. Our research shows that As, a highly toxic metalloid, and the $\mathrm{SiO}_{2} \mathrm{NPs}$, modified the processes of generating antioxidant compounds in ripe tomato fruit, usually with an increasing trend.

Author Contributions: Conceptualization, N.V.M.-V., G.C.-P. and A.J.-M.; Formal analysis, M.G.-M.; Project administration, A.J.-M.; Writing-original draft, M.G.-M.; Writing-review \& editing, N.V.M.-V., G.C.-P., A.B.-M., M.d.C.R.-C., S.G.-M. and A.J.-M.

Funding: This research received no external funding.

Conflicts of Interest: The authors declare no conflict of interest.

\section{References}

1. García-Martí, M.; Piñero, M.C.; García-Sanchez, F.; Mestre, T.C.; López-Delacalle, M.; Martínez, V.; Rivero, R.M. Amelioration of the oxidative stress generated by simple or combined abiotic stress through the $\mathrm{K}^{+}$and $\mathrm{Ca}^{2+}$ supplementation in tomato plants. Antioxidants 2019, 8, 81. [CrossRef]

2. Salehi, B.; Sharifi-Rad, R.; Sharopov, F.; Namiesnik, J.; Roointan, A.; Kamle, M.; Kumar, P.; Martins, N.; Sharifi-Rad, J. Beneficial effects and potential risks of tomato consumption for human health: An overview. Nutrition 2019, 62, 201-208. [CrossRef] [PubMed]

3. Stajčić, S.; Ćetković, G.; Čanadanović-Brunet, J.; Djilas, S.; Mandić, A.; Četojević-Simin, D. Tomato waste: Carotenoids content, antioxidant and cell growth activities. Food Chem. 2015, 172, 225-232. [CrossRef] [PubMed]

4. Xie, B.-x.; Wei, J.-j.; Zhang, Y.-t.; Song, S.-w.; Su, W.; Sun, G.-w.; Hao, Y.-w.; Liu, H.-c. Supplemental blue and red light promote lycopene synthesis in tomato fruits. J. Integr. Agric. 2019, 18, 590-598. [CrossRef]

5. Azeez, L.; Adeoye, M.D.; Majolagbe, T.A.; Lawal, A.T.; Badiru, R. Antioxidant activity and phytochemical contents of some selected Nigerian fruits and vegetables. Am. J. Anal. Chem. 2012, 2, 209-213.

6. Kim, D.-O.; Padilla-Zakour, O.I.; Griffiths, P.D. Flavonoids and Antioxidant Capacity of Various Cabbage Genotypes at Juvenile Stage. J. Food Sci. 2004, 69, 685-689. [CrossRef]

7. Cao, S.-Y.; Zhao, C.-N.; Gan, R.-Y.; Xu, X.-Y.; Wei, X.-L.; Corke, H.; Atanasov, A.G.; Li, H.-B. Effects and mechanisms of tea and its bioactive compounds for the prevention and treatment of cardiovascular diseases: An updated review. Antioxidants 2019, 8, 166. [CrossRef]

8. Otero, X.L.; Tierra, W.; Atiaga, O.; Guanoluisa, D.; Nunes, L.M.; Ferreira, T.O.; Ruales, J. Arsenic in rice agrosystems (water, soil and rice plants) in Guayas and Los Ríos provinces, Ecuador. Sci. Total Environ. 2016, 573, 778-787. [CrossRef]

9. Zvobgo, G.; Lwalaba, J.L.W.; Sagonda, T.; Mapodzeke, J.M.; Muhammad, N.; Shamsi, I.H.; Zhang, G.-p. Alleviation of arsenic toxicity by phosphate is associated with its regulation of detoxification, defense, and transport gene expression in barley. J. Integr. Agric. 2019, 18, 381-394. [CrossRef]

10. Heikens, A. Arsenic Contamination of Irrigation Water, Soil and Crops in Bangladesh: Risk Implications for Sustainable Agriculture and Food Safety in Asia; RAP Publication 2006/20; Food and Agriculture Organization of the United Nations, Regional Office for Asia and the Pacific: Bangkok, Thailand, 2006.

11. Ruíz-Huerta, E.A.; de la Garza Varela, A.; Gómez-Bernal, J.M.; Castillo, F.; Avalos-Borja, M.; SenGupta, B.; Martínez-Villegas, N. Arsenic contamination in irrigation water, agricultural soil and maize crop from an abandoned smelter site in Matehuala, Mexico. J. Hazard. Mater. 2017, 339, 330-339. [CrossRef]

12. Althobiti, R.A.; Sadiq, N.W.; Beauchemin, D. Realistic risk assessment of arsenic in rice. Food Chem. 2018, 257, 230-236. [CrossRef] [PubMed] 
13. Liao, X.; Fu, Y.; He, Y.; Yang, Y. Occurrence of arsenic in fruit of mango plant (Mangifera indica L.) and its relationship to soil properties. Catena 2014, 113, 213-218. [CrossRef]

14. Marmiroli, M.; Pigoni, V.; Savo-Sardaro, M.L.; Marmiroli, N. The effect of silicon on the uptake and translocation of arsenic in tomato (Solanum lycopersicum L.). Environ. Exp. Bot. 2014, 99, 9-17. [CrossRef]

15. Marmiroli, M.; Mussi, F.; Imperiale, D.; Lencioni, G.; Marmiroli, N. Abiotic stress response to As and As $+\mathrm{Si}$, composite reprogramming of fruit metabolites in tomato cultivars. Front. Plant Sci. 2017, 8, 1-17. [CrossRef]

16. Finnegan, P.M.; Chen, W. Arsenic toxicity: The effects on plant metabolism. Front. Physiol. 2012, 3, 1-18. [CrossRef]

17. Mitra, A.; Chatterjee, S.; Moogouei, R.; Gupta, D. Arsenic accumulation in rice and probable mitigation approaches: A review. Agronomy 2017, 7, 67. [CrossRef]

18. George, B.; Kaur, C.; Khurdiya, D.S.; Kapoor, H.C. Antioxidants in tomato (Lycopersium esculentum) as a function of genotype. Food Chem. 2004, 84, 45-51. [CrossRef]

19. Jimenez, A.; Creissen, G.; Kular, B.; Firmin, J.; Robinson, S.; Verhoeyen, M.; Mullineaux, P. Changes in oxidative processes and components of the antioxidant system during tomato fruit ripening. Planta 2002, 214, 751-758. [CrossRef]

20. De la Rosa, G.; García-Castañeda, C.; Vázquez-Núñez, E.; Alonso-Castro, Á.J.; Basurto-Islas, G.; Mendoza, Á.; Cruz-Jiménez, G.; Molina, C. Physiological and biochemical response of plants to engineered NMs: Implications on future design. Plant Physiol. Biochem. 2017, 110, 226-235. [CrossRef]

21. Juárez-Maldonado, A.; Ortega-Ortiz, H.; González-Morales, S.; Morelos-Moreno, Á.; Cabrera-de la Fuente, M.; Sandoval-Rangel, A.; Cadenas-Pliego, G.; Benavides-Mendoza, A. Nanoparticles and nanomaterials as plant biostimulants. Int. J. Mol. Sci. 2019, 20, 162. [CrossRef]

22. Hernández-Hernández, H.; González-Morales, S.; Benavides-Mendoza, A.; Ortega-Ortiz, H.; Cadenas-Pliego, G.; Juárez-Maldonado, A. Effects of chitosan-PVA and Cu nanoparticles on the growth and antioxidant capacity of tomato under saline stress. Molecules 2018, 23, 178. [CrossRef] [PubMed]

23. Alsaeedi, A.; El-Ramady, H.; Alshaal, T.; El-Garawany, M.; Elhawat, N.; Al-Otaibi, A. Silica nanoparticles boost growth and productivity of cucumber under water deficit and salinity stresses by balancing nutrients uptake. Plant Physiol. Biochem. 2019, 139, 1-10. [CrossRef] [PubMed]

24. Adrees, M.; Abbas, F.; Zia-ur-Rehman, M.; Ibrahim, M.; Rizwan, M.; Ali, S.; Farid, M.; Irshad, M.K.; Qayyum, M.F. Mechanisms of silicon-mediated alleviation of heavy metal toxicity in plants: A review. Ecotoxicol. Environ. Saf. 2015, 119, 186-197. [CrossRef] [PubMed]

25. Sanglard, L.M.V.P.; Martins, S.C.V.; Detmann, K.C.; Silva, P.E.M.; Lavinsky, A.O.; Silva, M.M.; Detmann, E.; Araújo, W.L.; DaMatta, F.M. Silicon nutrition alleviates the negative impacts of arsenic on the photosynthetic apparatus of rice leaves: An analysis of the key limitations of photosynthesis. Physiol. Plant. 2014, 152, 355-366. [CrossRef]

26. Steiner, A.A. A universal method for preparing nutrient solutions of a certain desired composition. Plant Soil 1961, 15, 134-154. [CrossRef]

27. USDA. United States Standards for Grades of Fresh Tomatoes; USDA: Washington, DC, USA, 1991; pp. 1-13.

28. Lopez-Vargas, E.R.; Ortega-ortiz, H.; Cadenas-pliego, G.; De-Alba-Romenus, K.; Cabrera-De-La-Fuente, M.; Benavides-Mendoza, A.; Juarez-Maldonado, A. Foliar application of copper nanoparticles increases the fruit quality and the content of bioactive compounds in tomatoes. Appl. Sci. 2018, 8, 20. [CrossRef]

29. Bradford, M.M. A rapid and sensitive method for the quantitation of microgram quantities of protein utilizing the principle of protein-dye binding. Anal. Biochem. 1976, 72, 248-254. [CrossRef]

30. Nagata, M.; Yamashita, I. Simple method for simultaneous determination of chlorophyll and carotenoids in tomato fruit. J. Jpn. Food Ind. 1992, 39, 925-928. [CrossRef]

31. Hung, C.Y.; Yen, G.C. Antioxidant activity of phenolic compounds isolated from Mesona procumbens Hemsl. J. Agric. Food Chem. 2002, 50, 2993-2997. [CrossRef]

32. Xue, T.; Hartikainen, H.; Piironen, V. Antioxidative and growth-promoting effect of selenium on senescing lettuce. Plant Soil 2001, 237, 55-61. [CrossRef]

33. Arvouet-Grand, A.; Vennat, B.; Pourrat, A.; Legret, P. Standardization of propolis extract and identification of principal constituents. J. Pharm. Belg. 1994, 49, 462-468. [PubMed]

34. Cumplido-Nájera, C.F.; González-Morales, S.; Ortega-Ortíz, H.; Cadenas-Pliego, G.; Benavides-Mendoza, A.; Juárez-Maldonado, A. The application of copper nanoparticles and potassium silicate stimulate the tolerance to Clavibacter michiganensis in tomato plants. Sci. Hortic. 2019, 245, 82-89. [CrossRef] 
35. Re, R.; Pellegrini, N.; Proteggente, A.; Pannala, A. Antioxidant activity applying an improved ABTS radical cation decolorization assay. Free Radic. Biol. Med. 1999, 26, 1231-1237. [CrossRef]

36. Velikova, V.; Yordanov, I.; Edreva, A. Oxidative stress and some antioxidant systems in acid rain-treated bean plants. Plant Sci. 2000, 151, 59-66. [CrossRef]

37. Pinheiro, F.C.; Amaral, C.D.B.; Schiavo, D.; Nóbrega, J.A. Determination of arsenic in fruit juices using inductively coupled plasma tandem mass spectrometry (ICP-MS/MS). Food Anal. Methods 2017, 10, 992-998. [CrossRef]

38. Stazi, S.R.; Cassaniti, C.; Marabottini, R.; Giuffrida, F.; Leonardi, C. Arsenic uptake and partitioning in grafted tomato plants. Hortic. Environ. Biotechnol. 2016, 57, 241-247. [CrossRef]

39. Beccaloni, E.; Vanni, F.; Beccaloni, M.; Carere, M. Concentrations of arsenic, cadmium, lead and zinc in homegrown vegetables and fruits: Estimated intake by population in an industrialized area of Sardinia, Italy. Microchem. J. 2013, 107, 190-195. [CrossRef]

40. Hettick, B.E.; Cañas-Carrell, J.E.; Martin, K.; French, A.D.; Klein, D.M. Arsenic uptake by muskmelon (Cucumis melo) plants from contaminated water. Bull. Environ. Contam. Toxicol. 2016, 97, 395-400. [CrossRef]

41. Yang, T.; Peng, H.; Whitaker, B.D.; Jurick, W.M. Differential expression of calcium/calmodulin-regulated SISRs in response to abiotic and biotic stresses in tomato fruit. Physiol. Plant. 2013, 148, 445-455. [CrossRef]

42. Ripoll, J.; Urban, L.; Staudt, M.; Lopez-Lauri, F.; Bidel, L.P.R.; Bertin, N. Water shortage and quality of fleshy fruits-making the most of the unavoidable. J. Exp. Bot. 2014, 65, 4097-4117. [CrossRef]

43. Gautier, H.; Diakou-Verdin, V.; Bénard, C.; Reich, M.; Buret, M.; Bourgaud, F.; Poëssel, J.L.; Caris-Veyrat, C.; Génard, M. How does tomato quality (sugar, acid, and nutritional quality) vary with ripening stage, temperature, and irradiance? J. Agric. Food Chem. 2008, 56, 1241-1250. [CrossRef] [PubMed]

44. Verheul, M.J.; Slimestad, R.; Tjøstheim, I.H. From producer to consumer: greenhouse tomato quality as affected by variety, maturity stage at harvest, transport conditions, and supermarket storage. J. Agric. Food Chem. 2015, 63, 5026-5034. [CrossRef] [PubMed]

45. Zhang, M.; Liang, Y.; Chu, G. Applying silicate fertilizer increases both yield and quality of table grape (Vitis vinifera L.) grown on calcareous grey desert soil. Sci. Hortic. 2017, 225, 757-763. [CrossRef]

46. Mushinskiy, A.A.; Aminova, E.V.; Korotkova, A.M. Evaluation of tolerance of tubers Solanum tuberosum to silica nanoparticles. Environ. Sci. Pollut. Res. 2018, 25, 34559-34569. [CrossRef]

47. Zhang, C.; Wang, L.; Zhang, W.; Zhang, F. Do lignification and silicification of the cell wall precede silicon deposition in the silica cell of the rice (Oryza sativa L.) leaf epidermis? Plant Soil 2013, 372, 137-149. [CrossRef]

48. Pinedo-Guerrero, Z.H.; Hernández-Fuentes, A.D.; Ortega-Ortiz, H.; Benavides-Mendoza, A.; Cadenas-Pliego, G.; Juárez-Maldonado, A. Cu nanoparticles in hydrogels of chitosan-PVA affects the characteristics of post-harvest and bioactive compounds of jalapeño pepper. Molecules 2017, $22,926$. [CrossRef]

49. Anthon, G.E.; LeStrange, M.; Barrett, D.M. Changes in $\mathrm{pH}$, acids, sugars and other quality parameters during extended vine holding of ripe processing tomatoes. J. Sci. Food Agric. 2011, 91, 1175-1181. [CrossRef]

50. Beckles, D.M. Factors affecting the postharvest soluble solids and sugar content of tomato (Solanum lycopersicum L.) fruit. Postharvest Biol. Technol. 2012, 63, 129-140. [CrossRef]

51. Iglesias, M.J.; García-López, J.; Collados-Luján, J.F.; López-Ortiz, F.; Díaz, M.; Toresano, F.; Camacho, F. Differential response to environmental and nutritional factors of high-quality tomato varieties. Food Chem. 2015, 176, 278-287. [CrossRef]

52. Juarez-Maldonado, A.; Ortega-Ortíz, H.; Pérez-Labrada, F.; Cadenas-Pliego, G.; Benavides-Mendoza, A. $\mathrm{Cu}$ Nanoparticles absorbed on chitosan hydrogels positively alter morphological, production, and quality characteristics of tomato. J. Appl. Bot. Food Qual. 2016, 89, 183-189. [CrossRef]

53. Cai, J.; Wang, P.; Tian, S.; Qin, G. Quantitative proteomic analysis reveals the involvement of mitochondrial proteins in tomato fruit ripening. Postharvest Biol. Technol. 2018, 145, 213-221. [CrossRef]

54. Szymanski, J.; Levin, Y.; Savidor, A.; Breitel, D.; Chappell-Maor, L.; Heinig, U.; Töpfer, N.; Aharoni, A. Label-free deep shotgun proteomics reveals protein dynamics during tomato fruit tissues development. Plant J. 2017, 90, 396-417. [CrossRef] [PubMed]

55. Zhang, F.-Q.; Wang, Y.-S.; Sun, C.-C.; Lou, Z.-P.; Dong, J.-D. A novel metallothionein gene from a mangrove plant Kandelia candel. Ecotoxicology 2012, 21, 1633-1641. [CrossRef] [PubMed]

56. Kısa, D.; Öztürk, L.; Doker, S.; Gökçe, İ. Expression analysis of metallothioneins and mineral contents in tomato (Lycopersicon esculentum) under heavy metal stress. J. Sci. Food Agric. 2017, 97, 1916-1923. [CrossRef] 
57. Gupta, D.K.; Nicoloso, F.T.; Schetinger, M.R.C.; Rossato, L.V.; Pereira, L.B.; Castro, G.Y.; Srivastava, S.; Tripathi, R.D. Antioxidant defense mechanism in hydroponically grown Zea mays seedlings under moderate lead stress. J. Hazard. Mater. 2009, 172, 479-484. [CrossRef]

58. Zhao, L.; Peralta-Videa, J.R.; Rico, C.M.; Hernandez-Viezcas, J.A.; Sun, Y.; Niu, G.; Servin, A.; Nunez, J.E.; Duarte-Gardea, M.; Gardea-Torresdey, J.L. $\mathrm{CeO}_{2}$ and $\mathrm{ZnO}$ nanoparticles change the nutritional qualities of cucumber (Cucumis sativus). J. Agric. Food Chem. 2014, 62, 2752-2759. [CrossRef]

59. Kinkade, M.P.; Foolad, M.R. Validation and fine mapping of $l y c_{12.1}$, a QTL for increased tomato fruit lycopene content. Theor. Appl. Genet. 2013, 126, 2163-2175. [CrossRef]

60. Elvira-Torales, L.I.; García-Alonso, J.; Periago-Castón, M.J. Nutritional importance of carotenoids and thT.M.A.B.alth: A review. Antioxidants 2019, 8, 229. [CrossRef]

61. Brandt, S.; Pék, Z.; Barna, É.; Lugasi, A.; Helyes, L. Lycopene content and colour of ripening tomatoes as affected by environmental conditions. J. Sci. Food Agric. 2006, 86, 568-572. [CrossRef]

62. Rosati, C.; Aquilani, R.; Dharmapuri, S.; Pallara, P.; Marusic, C.; Tavazza, R.; Bouvier, F.; Camara, B.; Giuliano, G. Metabolic engineering of beta-carotene and lycopene content in tomato fruit. Plant J. 2000, 24, 413-419. [CrossRef]

63. Tang, L.; Lee, A.H.; Su, D.; Binns, C.W. Fruit and vegetable consumption associated with reduced risk of epithelial ovarian cancer in southern Chinese women. Gynecol. Oncol. 2014, 132, 241-247. [CrossRef] [PubMed]

64. Shi, J.; Le Maguer, M. Lycopene in tomatoes: Chemical and physical properties affected by food processing. Crit. Rev. Food Sci. Nutr. 2000, 40, 1-42. [CrossRef] [PubMed]

65. Zhou, Y.; Diao, M.; Chen, X.; Cui, J.; Pang, S.; Li, Y.; Hou, C.; Liu, H.-y. Application of exogenous glutathione confers salinity stress tolerance in tomato seedlings by modulating ions homeostasis and polyamine metabolism. Sci. Hortic. 2019, 250, 45-58. [CrossRef]

66. Zhou, Y.; Wen, Z.; Zhang, J.; Chen, X.; Cui, J.; Xu, W.; Liu, H.-y. Exogenous glutathione alleviates salt-induced oxidative stress in tomato seedlings by regulating glutathione metabolism, redox status, and the antioxidant system. Sci. Hortic. 2017, 220, 90-101. [CrossRef]

67. Rojas-Loria, C.C.; Favela-Torres, E.; González-Márquez, H.; Volke-Sepúlveda, T.L. Role of glutathione and glutathione S-transferase in lead tolerance and bioaccumulation by Dodonaea viscosa (L.) Jacq. Acta Physiologiae Plantarum. 2014; 36, 2501-2510. [CrossRef]

68. Hasan, M.K.; Liu, C.; Wang, F.; Ahammed, G.J.; Zhou, J.; Xu, M.X.; Yu, J.Q.; Xia, X.J. Glutathione-mediated regulation of nitric oxide, S-nitrosothiol and redox homeostasis confers cadmium tolerance by inducing transcription factors and stress response genes in tomato. Chemosphere 2016, 161, 536-545. [CrossRef] [PubMed]

69. Tripathi, P.; Tripathi, R.D.; Singh, R.P.; Dwivedi, S.; Goutam, D.; Shri, M.; Trivedi, P.K.; Chakrabarty, D. Silicon mediates arsenic tolerance in rice (Oryza sativa L.) through lowering of arsenic uptake and improved antioxidant defence system. Ecol. Eng. 2013, 52, 96-103. [CrossRef]

70. Fenech, M.; Amaya, I.; Valpuesta, V.; Botella, M.A. Vitamin C content in fruits: Biosynthesis and regulation. Front. Plant Sci. 2019, 9, 1-21. [CrossRef]

71. Leiva-Brondo, M.; Valcárcel, M.; Cortés-Olmos, C.; Roselló, S.; Cebolla-Cornejo, J.; Nuez, F. Exploring alternative germplasm for the development of stable high vitamin C content in tomato varieties. Sci. Hortic. 2012, 133, 84-88. [CrossRef]

72. Roberts, P.; Jones, D.L.; Edwards-Jones, G. Yield and vitamin C content of tomatoes grown in vermicomposted wastes. J. Sci. Food Agric. 2008, 2567, 2563-2567. [CrossRef]

73. Wohlrab, C.; Phillips, E.; Dachs, G.U. Vitamin C transporters in cancer: Current understanding and gaps in knowledge. Front. Oncol. 2017, 7, 5-10. [CrossRef]

74. Ren, S.-C.; Sun, J.-T. Changes in phenolic content, phenylalanine ammonia-lyase (PAL) activity, and antioxidant capacity of two buckwheat sprouts in relation to germination. J. Funct. Foods 2014, 7, 298-304. [CrossRef]

75. Yang, C.S.; Maliakal, P.; Meng, X. Inhibition of carcinogenesis by tea. Annu. Rev. Pharm. Toxicol. 2002, 42, 25-54. [CrossRef] [PubMed]

76. Pereira, D.M.; Valentão, P.; Pereira, J.A.; Andrade, P.B. Phenolics: From chemistry to biology. Molecules 2009, 14, 2202. [CrossRef] 
77. Vega, I.; Nikolic, M.; Godoy, K.; La, D.; Mora, L. Silicon improves the production of high antioxidant or structural phenolic compounds in barley cultivars under aluminum stress. Agronomy 2019, 9, 388. [CrossRef]

78. Ahn-Jarvis, J.H.; Parihar, A.; Doseff, A.I. Dietary flavonoids for immunoregulation and cancer: Food design for targeting disease. Antioxidants 2019, 8, 202. [CrossRef]

79. Sudhakaran, M.; Sardesai, S.; Doseff, A.I. Flavonoids: New frontier for immuno-regulation and breast cancer control. Antioxidants 2019, 8, 103. [CrossRef]

80. Brunetti, C.; Fini, A.; Sebastiani, F.; Gori, A.; Tattini, M. Modulation of phytohormone signaling: A primary function of flavonoids in plant-environment interactions. Front. Plant Sci. 2018, 9, 1-8. [CrossRef]

81. Vinha, A.F.; Alves, R.C.; Barreira, S.V.P.; Castro, A.; Costa, A.S.G.; Oliveira, M.B.P.P. Effect of peel and seed removal on the nutritional value and antioxidant activity of tomato (Lycopersicon esculentum L.) fruits. LWT Food Sci. Technol. 2014, 55, 197-202. [CrossRef]

82. Reddivari, L.; Hale, A.L.; Miller, J.C. Determination of phenolic content, composition and their contribution to antioxidant activity in specialty potato selections. Am. J. Potato Res. 2007, 84, 275-282. [CrossRef]

83. Klunklin, W.; Savage, G. Effect on quality characteristics of tomatoes grown under well-watered and drought stress conditions. Foods 2017, 6, 56. [CrossRef]

84. Floegel, A.; Kim, D.O.; Chung, S.J.; Koo, S.I.; Chun, O.K. Comparison of ABTS/DPPH assays to measure antioxidant capacity in popular antioxidant-rich US foods. J. Food Compos. Anal. 2011, 24, 1043-1048. [CrossRef]

85. Sánchez-Rodríguez, E.; Rubio-Wilhelmi, M.M.; Cervilla, L.M.; Blasco, B.; Rios, J.J.; Rosales, M.A.; Romero, L.; Ruiz, J.M. Genotypic differences in some physiological parameters symptomatic for oxidative stress under moderate drought in tomato plants. Plant Sci. 2010, 178, 30-40. [CrossRef]

86. Yao, G.F.; Wei, Z.Z.; Li, T.T.; Tang, J.; Huang, Z.Q.; Yang, F.; Li, Y.H.; Han, Z.; Hu, F.; Hu, L.Y.; et al. Modulation of enhanced antioxidant activity by hydrogen sulfide antagonization of ethylene in tomato fruit ripening. J. Agric. Food Chem. 2018, 66, 10380-10387. [CrossRef]

87. Islam, E.; Khan, M.T.; Irem, S. Biochemical mechanisms of signaling: Perspectives in plants under arsenic stress. Ecotoxicol. Environ. Saf. 2015, 114, 126-133. [CrossRef]

88. Zhao, Y.; Tu, K.; Su, J.; Tu, S.; Hou, Y.; Liu, F.; Zou, X. Heat treatment in combination with antagonistic yeast reduces diseases and elicits the active defense responses in harvested cherry tomato fruit. J. Agric. Food Chem. 2009, 57, 7565-7570. [CrossRef]

89. Zhao, R.; Hao, J.; Xue, J.; Liu, H.; Li, L. Effect of high-voltage electrostatic field pretreatment on the antioxidant system in stored green mature tomatoes. J. Sci. Food Agric. 2011, 91, 1680-1686. [CrossRef] 